\title{
Animal infections by vaccinia-like viruses in the state of Rio de Janeiro: An expanding disease ${ }^{1}$
}

\author{
Hermann G. Schatzmayr ${ }^{2}$, Bruno R. Simonetti ${ }^{2}$, Danielle C. Abreu², José P. \\ Simonetti ${ }^{2}$, Sandra R. Simonetti ${ }^{2}$, Renata V.C. Costa ${ }^{3}$, Márcia Cristina R. \\ Gonçalves ${ }^{2}$, Paulo Sérgio D'Andréa ${ }^{4}$, Marconny Gerhardt ${ }^{4}$, Manuel E. Vieira \\ Silva², José C. Farias-Filho² and Ortrud M. Barth²
}

\begin{abstract}
Schatzmayr H.G., Simonetti B.R., Abreu D.C., Simonetti J.P., Simonetti S.R., Costa R.V.V., Gonçalves M.C.R., D'Andréa P.S., Gerhardt M.., Silva M.E.V., FariasFilho J.C. \& Barth O.M. 2009. Animal infections by vaccinia-like virus in the state of Rio de Janeiro: An expanding disease. Pesquisa Veterinária Brasileira 29(7):509-514. Laboratório de Morfologia e Morfogênese Viral, Instituto Oswaldo Cruz, Fiocruz, Avenida Brasil 4365, Rio de Janeiro, RJ 21040-900, Brazil. E-mail: hermann@ ioc.fiocruz.br

In the present study we investigated the presence of infections by vaccinia-like viruses in dairy cattle from 12 counties in the state of Rio de Janeiro in the last 9 years. Clinical specimens were collected from adult animals with vesicular/pustular lesions mainly in the udder and teats, and from calves with lesions around the nose and mouth. A plaque reduction neutralization test (PRNT) was applied to search for antibodies to Orthopoxvirus; the vesicular/pustular fluids and scabs were examined by PCR, electron microscopy (EM) and by inoculation in VERO cells for virus isolation. Antibodies to Orthopoxvirus were detected in most cases. The PCR test indicated a high nucleotide homology among the isolates and the vaccinia viruses (VACV) used as controls. By EM, typical orthopoxvirus particles were observed in some specimens. The agents isolated in tissue culture were confirmed as vaccinia-like viruses by EM and PCR. The HA gene of the vaccinia-like Cantagalo/IOC virus isolated in our laboratory was sequenced and compared with other vaccinia-like isolates, showing high homology with the original Cantagalo strain, both strains isolated in 1999 from dairy cattle. Antibodies to Orthopoxvirus were detected in one wild rodent (genus Akodon sp.) collected in the northwestern region of the state, indicating the circulation of poxvirus in this area. Nonetheless, PCR applied to tissue samples collected from the wild rodents were negative. Vesicular/pustular lesions in people in close contact with animals have been also recorded. Thus, the vaccinia-like virus infections in cattle and humans in the state seem to be an expanding condition, resulting in economic losses to dairy herds and leading to transient incapacitating human disease. Therefore, a possible immunization of the dairy cattle in the state should be carefully evaluated.
\end{abstract}

INDEX TERMS: Orthopoxvirus infections, PCR, neutralization test, electron microscopy, state of Rio de Janeiro.

\footnotetext{
${ }^{1}$ Received on December 6, 2008.

Accepted for publication on February 2I, 2009.

2 Laboratório de Morfologia e Morfogênese Viral, Instituto Oswaldo Cruz, Fiocruz, Avenida Brasil 4365, Rio de Janeiro, RJ 21040-900, Brazil. ${ }^{*}$ Corresponding author: hermann@ioc.fiocruz.br

${ }^{3}$ Secretaria de Agricultura, Pecuária, Pesca e Abastecimento/SEEPA, Alameda São Boaventura 770, Fonseca, Niterói, RJ 24120-191, Brazil.

${ }^{4}$ Laboratório de Biologia e Parasitologia de Mamíferos Silvestres Reservatórios, Instituto Oswaldo Cruz, Rio de Janeiro, RJ, Brazil.
}

RESUMO.- [Infecções animais por vírus semelhantes ao vaccínia no estado do Rio de Janeiro: uma doença em expansão.] Neste estudo avaliou-se a presença de infecções por vírus semelhantes ao vírus vaccínia (VACV) em gado leiteiro em 12 municípios no estado do Rio de Janeiro, ao longo dos últimos nove anos. Amostras clínicas foram coletadas de animais com vesículas, pústulas e crostas no úbere e tetas, e da região do nariz e da cavidade oral de bezerros. Um teste de neutralização viral 
por redução de placas foi desenvolvido para investigar a presença de anticorpos contra Orthopoxvirus. Os fluidos de vesículas / pústulas e as crostas foram testadas por PCR, microscopia eletrônica (ME) e por inoculação em células VERO para isolamento viral. Anticorpos contra Orthopoxvirus foram detectados na grande maioria dos animais. O teste de PCR demonstrou homologia entre os vírus isolados e amostras de vírus vaccínia usados como controles. Na ME, partículas típicas de Orthopoxvirus foram observadas em vários espécimes analisados. Os vírus isolados em cultivo celular foram confirmados como Orthopoxvirus por PCR e ME. O gene HA da amostra Cantagalo/IOC isolada em nosso laboratório foi seqüenciado e comparado com outras amostras semelhantes ao vaccínia, mostrando uma alta homologia com a amostra original Cantagalo, tendo sido as duas amostras isoladas em 1999 de gado leiteiro. Anticorpos para Orthopoxvirus foram detectados em um roedor silvestre do gênero Akodon sp. coletado na região noroeste do estado, sugerindo uma circulação de poxvírus na natureza. No entanto, os testes de PCR aplicados a tecidos de roedores silvestres foram negativos. Infecções vesiculares / pustulares em humanos que mantinham contato com os animais afetados também foram relatadas. Assim, infecções por amostras semelhantes ao vírus VACV em bovinos e em humanos parecem em expansão no estado, gerando perdas econômicas em animais e quadros de doença incapacitante temporária em pacientes humanos. Dessa forma, a possibilidade da imunização do gado leiteiro no estado deve ser devidamente avaliada.

TERMOS DE INDEXAÇÃO: Infecções por Orthopoxvirus, PCR, teste de neutralização, microscopia eletrônica, estado do Rio de Janeiro.

\section{INTRODUCTION}

The family Poxviridae comprises a group of virus naturally infecting humans and many other vertebrate species and insects as well. In vertebrates, these viruses cause mainly vesicopustular infections of different degrees of severity (Schatzmayr \& Azeredo-Costa 2005). The majority of human poxvirus infections are zoonotic while the smallpox virus and Molluscum contagiosum are solely human pathogens. Among the genera which are able to infect vertebrates, the Orthopoxvirus is the most important. This genus includes smallpox virus, whose human infection was eradicated from the world in 1977; rabbitpox; vaccinia virus, which is used for vaccine preparation against smallpox; cowpox, a zoonotic virus occurring mainly in rodents in Europe and parts of Asia and monkeypox, which circulates mainly in Africa in wild animals. This last virus was recently introduced into North America by importation of pet rodents (CDC 2003).

Since 1999, orthopoxvirus infections have been reported in the state of Rio de Janeiro (RJ) as a zoonotic disease, involving dairy cattle and people in contact with the affected animals (Damaso et al. 2000; Schatzmayr et al. 2000). The Cantagalo strain was characterized at molecular level as a vaccinia-like virus that resembled the vaccinia/IOC strain used for vaccine preparation in the past (Damaso et al. 2000). Later on, other orthopoxviruses, isolated mainly in the southeastern region of the country were also confirmed as vaccinia-like poxviruses (Schatzmayr et al. 2000, 2005, De Souza Trindade et al. 2003, Nagasse-Sugahara et al. 2004). The present article describes studies carried out in 12 counties in the northwestern and Paraíba river valley regions of Rio de Janeiro state (RJ) over the last 9 years. These studies aimed to confirm the presence of poxviruses in skin lesions of animals and the presence of human infections related to the animal disease, to characterize the circulating virus isolates and to contribute for a better understanding of the epidemiology of poxvirus infections in the state.

\section{MATERIALS AND METHODS}

Clinical specimens: Vesicular and pustular fluids, scabs and blood samples from dairy cattle presenting vesicopustular disease were received in the laboratory of Instituto Oswaldo Cruz for diagnosis. The specimens were originated from the municipalities of Cantagalo, Cordeiro, Santo Antonio de Padua, Aperibé, Cambuci and Miracema in the northwestern region and Valença, Barra do Piraí, Rio das Flores, Piraí, Rio Claro and Resende in the Paraiba river region of the state of Rio de Janeiro (Fig.1).

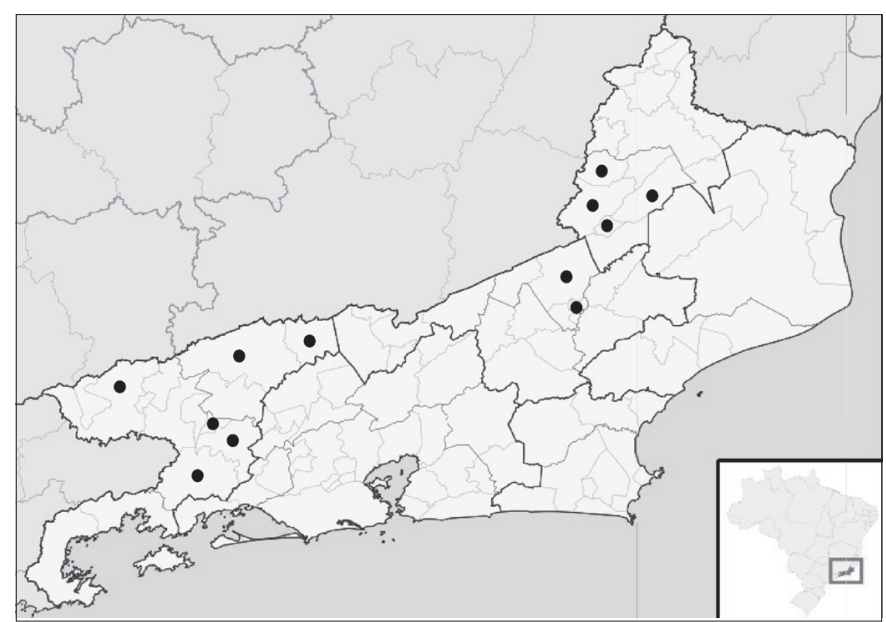

Fig.1. Counties in the state of Rio de Janeiro where animal infections have been confirmed by laboratory tests.

In Paraiba river valley the county of Valença represents 35.5 $\%$ of the farms with clinical cases, followed by Barra do Piraí with $19.3 \%$ and Resende with $16.1 \%$. Most of the cases occured from May to August, corresponding to the dry season. The specimens were sent to the laboratory by animal health authorities for etiologic confirmation Serum samples were obtained from most cases and skin specimens were collected only in acute cases. A total of 152 animal infections were studied, with 41 skin and 135 blood specimens being collected and analyzed. Data on the cases were obtained from the owners of the animals and from field investigations carried out by one of the authors in the Paraíba river area (RVCC).

Virus isolation: specimens collected from the skin lesions were grounded and treated with proportional volume of Eagle 
tissue culture medium plus antibiotics. The material was inoculated in a VERO cell strain permissive to poxvirus. The inoculated cells were observed for cytopathic effect (CPE) and the presence of the virus was confirmed by electron microscopy (EM) and polymerase chain reaction (PCR).

Electron microscopy: fragments of skin and vesicular fluids were prepared for transmission EM by dilution in distilled water and negative contrasting using PTA 1\% (Brenner \& Horne 1959). Observations were then made at 30,000x magnification in a Zeiss Electron Microscope, model 900. Tissue culture supernatants were contrasted and observed as described.

PCR and nucleotide sequencing: briefly, external primers (HAOUTR and HAOUTF) as previously described (Damaso 2000) were applied for amplification of a segment of $1171 \mathrm{bp}$ of the HA gene. Vaccinia-like virus strains isolated from the municipalities of Cordeiro, Cambuci, Miracema and Aperibé and the Cantagalo/IOC strain were included. As controls, the original Cantagalo strain and the Wyeth-NYBH vaccinia strain were also submitted to PCR (Fig.2). For sequencing of a genome region of Cantagalo/IOC strain, which has been isolated in same area and on the same occasion as the original Cantagalo strain, two internal primers(HAINTR and HAINTF) were used.

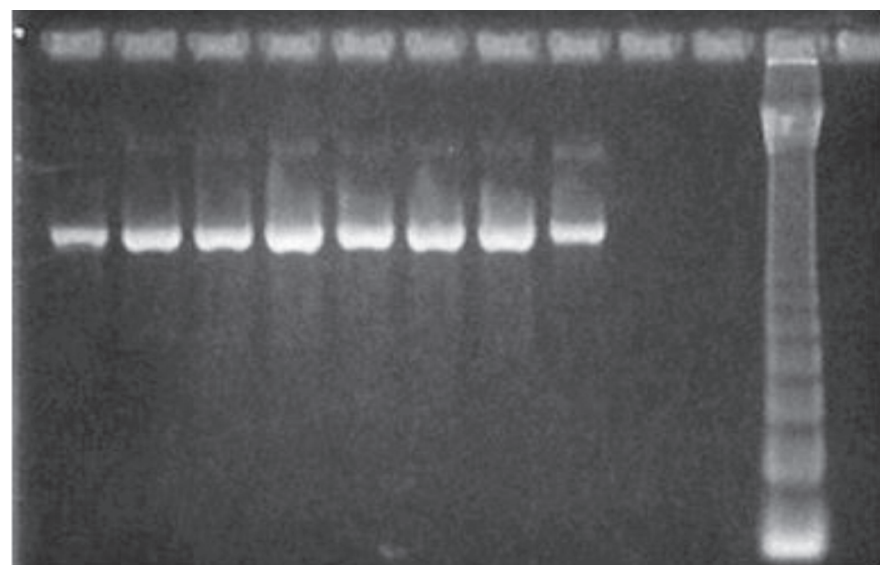

Fig.2. Results of the PCR test for the HA gene of pox virus in agarose gel 1.5\%. Result of the amplification (approx.1107 bp) by PCR of the strains: 1- Cordeiro 509; 2- Cambuci; 3Miracema; 4- Aperibé; 5- Cordeiro 510; 6- CTGV-IOC; 7CTGV; 8- CP (VV-NYBH Wyeth); 9- CN-BIO; 10- CN-H2O; 11- Ladder 123 bp.

Sequence alignment was performed using the Clustal W software and the phylogenetic tree was constructed using the MEGA 3.1 software, by means of the neighbor joining method under a matrix of genetic distances established by the Kimura two-parameter model. The bootstrap with 1000 replications was used to estimate the reliability of the predicted tree. The bootstrap values are indicated at the branch points in Figure 3.

Serology: the sera were submitted to a $50 \%$ plaquereduction neutralization test (PRNT), using the Cantagalo/IOC strain as the reference virus. Serum dilutions and a virus suspension containing approximately 40 plaque-forming units (pfu) in 100 microliters were incubated at $37^{\circ} \mathrm{C}$ for $1 \mathrm{~h}$ in cell culture microplates, followed by addition of a suspension of VERO cells. After $48 \mathrm{~h}$, the plates were stained with crystal violet and formaldehyde $1 \%$, washed and the plaques were counted under the microscope.

Rodent collection: small wild mammals were trapped in rural areas of the municipalities of Cordeiro and Cantagalo At each capture site, traps were set on linear transects with 20 trapping stations at $10 \mathrm{~m}$ intervals. All transects were geographically positioned using the GARMINO GPS 12 GPS receiver, referenced to WGS-84 (World Geodetic System, 1984). We used two types of live-traps: Sherman (H.B. Sherman Traps ${ }^{\circledR}, 7.62 \times$ $9.53 \times 30.48 \mathrm{~cm}$ ) and Tomahawk (Tomahawk Live Traps ${ }^{\circledR}, 40.64$ $x 12.70 \times 12.70 \mathrm{~cm}$ ) to capture small mammals weighing up to 3 $\mathrm{kg}$. The bait was a mixture of banana, bacon, oats and peanut butter. The total sampling effort was 260 trap-nights in Cordeiro and 440 trap-nights in the Paraíba do Sul locality (Cantagalo).

Preliminary identification of rodents at genus level was done in the field by external morphology, followed by confirmation by karyotyping (De Andrade et al. 2004).

All the animals were euthanized to carry out cytogenetic techniques and collection of blood and organs for poxvirus diagnosis, in accordance with bioethics protocols for animal use. The researchers used individual protection equipment (3M HEPA filters, biological level 3) and other biosafety methods, following protocols approved by the Biosafety Committee of the Oswaldo Cruz Institute. The animal trapping was licensed by the Brazilian Institute for the Environment and Renewable Natural Resources (Instituto Brasileiro do Meio Ambiente e dos Recursos Naturais Renováveis, IBAMA), under license numbers 068/2005 and 225/ 2006.

Serum samples from 17 rodents were tested for antibodies as described. Tissue fragments (liver, kidneys, lungs) were also collected and brought to the laboratory in liquid nitrogen, grounded and analysed by PCR and virus isolation. All techniques using the rodent specimens were carried out in a laboratory certified at Biosafety level 3, considering the possible presence of other pathogenic viruses in the wild animals.

\section{RESULTS}

Analysis of specimens collected in 12 municipalities confirmed the association of orthopoxviruses with vesicular disease in 152 animals, by at least one of the techniques applied. A total of 25 orthopoxviruses were isolated in tissue culture and/or detected by PCR.

In Figure 2, PCR amplifications of the HA gene of five isolates are compared with the Cantagalo/IOC strain, the original UFRJ Cantagalo strain and the Wyeth vaccinia strain. The figure shows PCR amplification of all five isolates, indicating homology at nucleotide level with the controls.

Figure 3 shows a phylogenetic analysis of the HA orthopoxvirus gene, demonstrating homology between the Cantagalo/IOC and original Cantagalo strains and a close relationship with the IOC vaccine strain, which has been used as antigen for the serology.

Table 1 presents the results of the different methods used to identify/characterize the viruses. Since PCR was introduced in our laboratory by 1995, evaluation of sensitivity of the tests were possible only in specimens tested thereafter. In those samples in which PCR and virus isolation were carried out concomitantly, the PCR test was more sensitive, as expected.

Electron microscopy shows typical morphology of orthopoxvirus virions (Fig.4).

Antibody testing alone was responsible for the definitive 


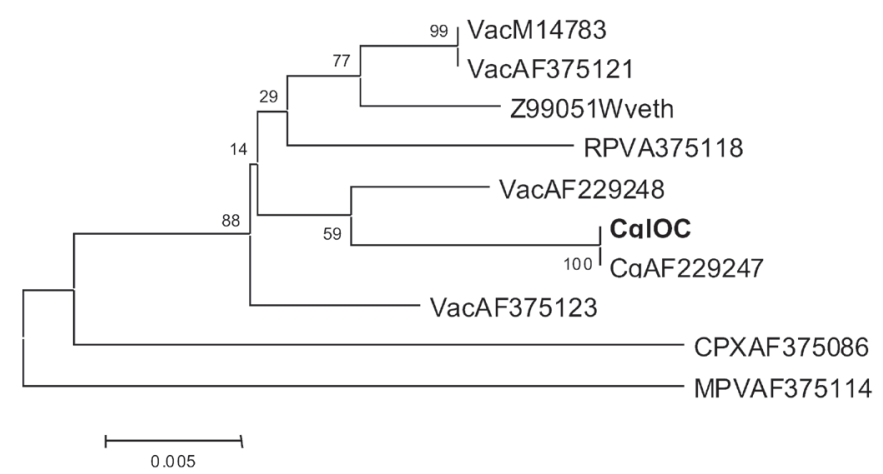

Fig.3. Phyllogenetic analysis of Cantagalo IOC strain. The comparative analysis of the DNA sequences (gene HA of Orthopoxvirus) was made using CLUSTAL software. The phyllogenetic tree was constructed applying the neighborjoining method (bootstrap $=1000$ ), using the program MEGA 3.1 (Molecular Evolutionary Genetics Analysis, Pennsylvania State University). The genetic distance was obtained by the proportional distance method (two paramets model, Kimura). The reference sequences used were: Vac variants M14783, Vac indw AF375121, Z99051 Wyeth, RPV rev AF375118, Vac IOC AF229248, Cg IOC, CgAF229247, Vac len AF375123, CPX 895 AF375086, MPV wmp AF375114.

Table 1. Laboratorial results of the specimens from bovines suspected of poxvirus infection in 12 counties of the state of Rio de Janeiro, 1999-2007

\begin{tabular}{lcc}
\hline & Positive samples & Negative samples \\
\hline RT-PCR test & 22 & 09 \\
Vírus isolation & 13 & 14 \\
Electron microscopy & 16 & 09 \\
Neutralization test & 100 & 30
\end{tabular}

diagnostic in most cases, being sera dilutions $>1 / 10$ accepted as positive In some animals, titers as high as 1280 were observed. Antibodies to orthopoxviruses were detected at dilution of $1 / 20$ in three subsequent antibody titration tests in the serum of one rodent genus (Akodon

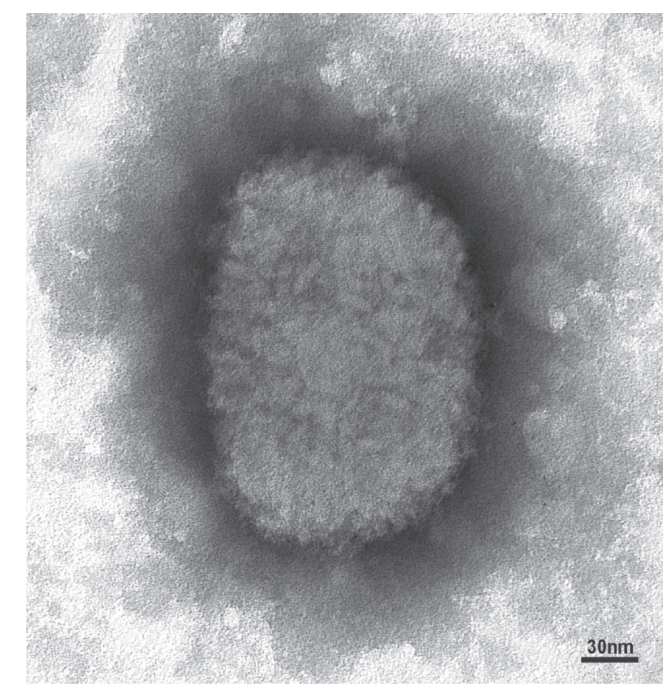

Fig.4. Orthopoxvirus particle observed using electron microscopy technique in bovine specimen.

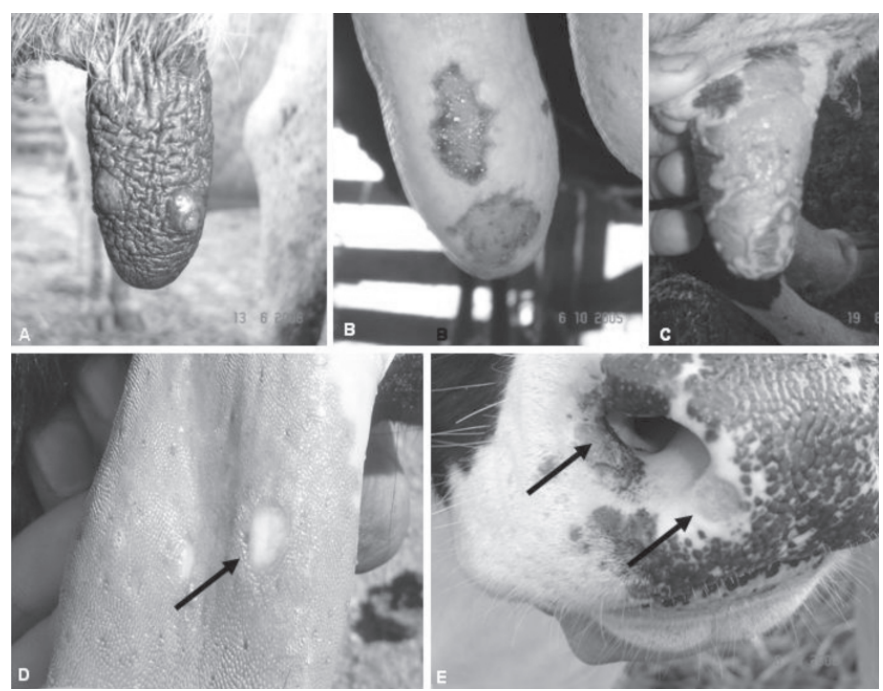

Fig.5. Lesions observed in the udder (A, B, C), in calf tongue (D) and nose (E).

sp.) out of 17 animals collected in the same week. Nonetheless, no virus could be detected in tissues by virus isolation or PCR in any of the rodents collected.

The lesions in the adult cattle were observed in the udder and teats and in the lips and around the noses of calves. In one calf which was positive by PCR and neutralizing antibodies, lesions were detected also in the tongue (Fig.5).

Typically, after the vesicle/pustular stage, the membrane covering the lesion dried and pelt off, leaving a bloody painful wound, sometimes reaching large areas in the teats (Fig.5). The evolution of the vesicle to the complete healing took about 3 to 4 weeks.

Human cases were observed in workers in direct contact with affected animals, yet no human-to-human transmission was reported. In more than $80 \%$ of the patients only lesions in the hands and fingers were observed. Almost all patients could not attend their normal activities during the disease. Most patients $(97.3 \%$ of 22) recorded pain in the lesions, fever and lymph node swelling, headache, sudoresis and prostration. The incubation period, after the first contact with the infected animals was of 5 to 7 days and the clinical disease lasted about 3 weeks. Cases of poxvirus infection in humans and cattle had been confirmed at other municipalities but so far have not been confirmed at laboratory level.

\section{DISCUSSION}

Orthopoxvirus infections in human and animals have been described in several countries (Lum et al. 1967, Mesquita \& Schatzmayr 1969, Topciu et al. 1976, Schatzmayr et al. 2000, 2005). Nagasse-Sugahara et al. (2004), studying 74 cases of a vesicular human disease in the Paraíba river valley in the state of São Paulo, indicated the circulation of poxviruses in the area.

In Brazil, the smallpox vaccination in rural areas has been carried out farm-by-farm. Careless handling of the 
live vaccine - containing virus titers as high as $10^{8}$ infectious particles per mililiter - possibly allowed the dissemination of the vaccine virus in nature. It is very likely that vaccine viruses had been introduced in nature in different occasions. Although smallpox vaccination was discontinued in the country in the 70s, vaccinia-like viruses have been isolated from animals confirming that vaccinia-like virus are circulating in the country, a fact already accepted by the international literature (Regnery 2007).

In the state of Rio de Janeiro, animal and human poxvirus infections have been repeatedly described along the years (Silva \& Moraes 1961, Mesquita \& Schatzmayr 1969, De Souza et al. 2003, Costa et al 2007, Donatele et al. 2007, Simonetti et al 2007). In this article, the clinical lesions observed in the animals confirmed observations of these authors. Vesicles occurred in the udder, particularly in the teats, with coalescence of vesicles resulting in large vesicular lesions that erupted and became covered by scabs. Permanent udder lesions were observed as well as mastitis, which resulted in economic losses, besides the reduction in milk production.

The lesions in the tongue of one calf suggest the presence of virus in the oral cavity and probably the saliva could transmit the virus by direct contact with other animals in the herd. Nevertheless, this observation deserves further studies. The disease was transmitted only to calves suckling in infected mothers, but not in those drinking milk in tanks, suggesting that transmission occurred only by direct contact.

Animals from one of the farms with vesicular/pustular disease were negative to Orthopoxvirus by all laboratory techniques applied. Other agents causing vesicular disease like parapoxviruses might have been involved in theses cases as already described in sheep in the state (Barth et al. 2005).

Our PCR results showed that the viruses recovered from sick animals match with the Cantagalo strain, confirming that vaccinia-like virus strains circulating in the state are close related to the original Cantagalo strain (Fig.2, lanes 1-7). This strain has been demonstrated to be, at molecular level, similar to the strain used for vaccine preparation at the Oswaldo Cruz Institute (Damaso et al. 2000).

In other nearby counties, vesicular/pustular diseases have also been described in dairy cattle, suggesting that the virus is present in large areas of the state. A surveillance system has been established at Paraíba valley and other municipalities are being monitored. According to informations obtained from local residents, similar episodes of vesicular disease have been observed in the Paraíba valley, along the last years and even just after the smallpox mass vaccination campaign, about forty years ago.

The presence of antibodies to orthopoxvirus in just one wild rodent of genus Akodon is not enough to confirm the presence of virus circulation in rodents in the state. However this hypothesis is well supported, since the first vaccinia-like virus isolated in the country in nature was present in the whole blood from a rodent (Oryzomys sp.) in the Amazon region (Fonseca et al. 1998). Cotia virus, also a poxvirus was isolated in a sentinel rodent in the state of São Paulo (Lopes et al. 1965, Ueda et al. 1978), confirming that this group is circulating in arthropods in the country.

These data support that further field studies are needed for confirming the possible role of wild rodents as reservoirs for orthopoxviruses in the state. In this sense, a recent review emphasized the capacity of orthopoxviruses to adapt to new animal species (Regnery 2007). Field studies are needed for confirming the possible role of reservoirs like wild rodents and vectors, which might be related to poxviruses transmission in the state.

According to the data obtained over the years, Orthopoxvirus infections seem to be spreading in the state of Rio de Janeiro and should be considered a new emerging zoonotic disease. This disease may cause temporary incapacitating human disease that may be more severe in immunosuppressed individuals. In dairy cattle, such infections cause important economic losses, due to reduction in milk production and permanent lesions on the udder. Therefore, the possibility of immunization of dairy cattle against poxviruses should be carefully evaluated.

Acknowledgements.- To all the professionals and animal owners who collaborated in obtaining the specimens and the epidemiological data. Financial support: CNPq (Proc.472.332/2006-0), FAPERJ (Proc.E-26/ 171.152/2005) and Oswaldo Cruz Foundation.

\section{REFERENCES}

Barth O.M., Majerowicz S., Romijn P.C., Silva R.C.F., Costa C.H.C., Otavio J.R., Pires A.R. \& Schatzmayr H.G. 2005. Occurrence of parapoxvirus infections in ovine flocks in the state of Rio de Janeiro. Virus Rev. Res. 10:23-26.

Brenner S. \& Horne R.W. 1959. A negative staining method for highresolution electron microscopy of viruses. Biochim. Biophsys. Acta 34:103-104.

Centers for Disease Control and Prevention 2003. Multistate outbreak of monkeypox - Illinois, Indiana and Wisconsin. J. Am. Med. Assoc. 290 (Jul.2):30-31.

Costa R.V.C., Simonetti B.R., Abreu D.C., Simonetti J.P., Gonçalves M.C.R., Silva M.E.V., Brust L.A.C., Barth O.M. \& Schatzmayr H.G. 2007. Animal infections by vaccinia-like virus in the state of Rio de Janeiro:2-Paraiba river valley. Virus Rev. Res. 12:37-42.

Damaso C.R.A., Esposito J.J., Condit R.C. \& Moussatché N. 2000. An emergent poxvirus from humans and cattle in Rio de Janeiro state: Cantagalo virus may derive from Brazilian smallpox vaccine. Virology 277:439-449.

De Andrade A.F.B., Bonvicino C.R., Briani D.C. \& Kasahara S. 2004. Karyologic diversification and phylogenetic relationships of the genus Thalpomys (Rodentia, Sigmodontidae). Acta Theriologica 49:181189.

De Souza Trindade G., Fonseca F.G., Marques J.T., Nogueira M.L., Mendes L.C., Borges A.S., Peiro J.R., Pittuco A.M., Bonjardin C.A., Ferreira P.C. \& Kroon E.G. 2003. Araçatuba virus: A vaccinia like virus associated with infection in humans and cattle. Emerg. Infect. Dis. 9:155-160

Donatele D.M., Travassos C.E.P.F., Leite J.A. \& Kroon E.G. 2007. Epidemiologia da poxvirose bovina no Estado do Espírito Santo, Brasil. Braz. J. Vet. Res. Anim. Sci. 44:275-282. 
Fonseca F.G., Lanna M.C.S., Campos M.A.S., Kitajima E.W., Perez J.N., Golgher R.R., Ferreira P.C.P. \& Kroon E.G. 1998. Morphological and molecular characterization of the poxvirus BeAn 58058. Arch. Virol. 143:1171-1186.

Lopes O.S., Lacerda J.P.G., Fonseca I.E.M., Castro D.P., Forattini O.P. \& Rabello E.X. 1965. Cotia virus: New agent isolated from sentinel mice in São Paulo, Brazil. Am. J. Trop. Med. Hyg. 14:156-157.

Lum G.S., Soriano F., Trejos A. \& Lierena J. 1967. Vaccinia epidemic and epizootic in El Salvador. Am. J. Trop. Med. Hyg. 16:332-338.

Mesquita J.A. \& Schatzmayr H.G. 1969. Estudos laboratoriais de infecções humanas e de bovinos com vírus do grupo pox. Revta Soc. Bras. Med. Trop. 3:171-175.

Nagasse-Sugahara T.K., Kisielius J.J., Ueda-Ito M., Curti S.P., Figueiredo C.A. \& Cruz A.S. 2004. Human vaccinia-like virus outbreaks in São Paulo and Goiás States, Brazil: Virus detection, isolation and identification. Revta Inst. Med. Trop. São Paulo 46:315-322.

Regnery R.L. 2007. Poxvirus and passive quest for novel hosts. Curr. Top. Microbiol. Immunol 315:345-361.

Schatzmayr H.G. \& Costa E.A. 2005. Poxvirus, p.1936-1944. In: Coura J.R. (Ed.), Dinâmica das Doenças Infecciosas e Parasitárias. Editora Guanabara, Rio de Janeiro.
Schatzmayr H.G., Lemos E.R., Mazur C., Schubach A., Majerowicz S., Rozental T., Schubach M.C., Bustamante M.C. \& Barth O.M. 2000. Detection of poxviruses associated with human cases in the state of Rio de Janeiro: A preliminary report. Mem. Inst. Oswaldo Cruz 95:625627.

Schatzmayr H.G., Romijin P.C., Barreto D.F., Silva E.E., Farias-Filho J.C., Tavares A.F.A. \& Barth O.M. 2005. An outbreak of vesicopustular disease in humans and dairy cattle in the state of Rio de Janeiro. Virus Rev. Res. 10:61-63.

Silva P.L. \& Moraes L.T. 1961. Nota sobre a ocorência da varíola bovina no estado do Rio de Janeiro. 1 Estudo da doença no município de Três Rios. Veterinária, Rio de J., 14:31-35.

Simonetti B.R., Abreu D.C., Simonetti J.P., Gonçalves M.C.R., Silva M.E.V., Barth O.M. \& Schatzmayr H.G. 2007. Animal infections by vaccinia-like viruses in the state of Rio de Janeiro:1-Northwestern region. Virus Rev. Res. 12:32-36.

Topciu V., Luca I., Moldovan E., Stoianovici V., Plavosin L. \& Milin D. 1976. Transmission of vaccinia virus from vaccinated milkers to cattle. Virology 27:279-282.

Ueda Y., Tsuruhara K.R. \& Tagaya T. 1978. Studies on Cotia virus: An unclassified poxvirus. J. Gen. Virol. 40:263-276. 